Journal of Current and Advance Medical Research

January 2019, Vol. 6, No. 1, pp. 6-9

http://www.banglajol.info/index.php/JCAMR

ISSN (Print) 2313-447X

ISSN (Online) 2413-323X

NLM Catalog ID 101673828

DOI: https://doi.org/10.3329/jcamr.v6i1.40774

ORIGINAL ARTICLE OPEN $\bigcirc$ ACCESS

\title{
Pattern of Tumour among Hepatocelluar Carcinoma Patients attended at a Tertiary Care Hospital in Dhaka City
}

\author{
Md. Akter Hossain ${ }^{1}$, Md. Saiful Haque ${ }^{2}$, Md. Ashikur Rahman ${ }^{3}$ Zinat Nasreen ${ }^{4}$, Mostaque Ahmed Bhuiya ${ }^{5}$, \\ Abu Bakar Siddique ${ }^{6}$
}

\begin{abstract}
${ }^{1}$ Associate Professor, Department of Radiology \& Imaging, National Institute of Ophthalmology \& Hospital, Dhaka, Bangladesh; ${ }^{2}$ Associate Professor, Department of Radiology \& Imaging, Diabetic Association Medical College, Faridpur, Bangladesh; ${ }^{3}$ Associate Professor, Department of Radiology \& Imaging, MAG Osmani Medical College, Sylhet, Bangladesh; ${ }^{4}$ Assistant Professor, Department of Radiology \& Imaging, National Institute of Ophthalmology \& Hospital, Dhaka, Bangladesh; ${ }^{5}$ Associate Professor, Department of Radiology \& Imaging, MAG Osmani Medical College, Sylhet, Bangladesh; ${ }^{6}$ Assistant Professor, Department of Radiology \& Imaging, National Institute of Ophthalmology \& Hospital, Dhaka, Bangladesh
\end{abstract}

[Received on: 2 July 2018; Reviewed on: 30 October 2018; Accepted on: 19 November 2018; Published on: 1 January 2019]

\section{Abstract}

Background: The pattern of hepatocelluar carcinoma may vary in different patients. Objective: The purpose of the present study was to see the pattern of hepatocelluar carcinoma among the patients attended at a tertiary care hospital in Dhaka city. Methodology: This cross-sectional study was carried out in the Department of Radiology and Imaging at Dhaka Medical College, Dhaka and Banghabandhu Sheikh Mujib Medical University, Dhaka from January 2007 to May 2008 for a period of around one and half year. All the patients presented with hepatocellular carcinoma at the age group of more than 20 years with both sexes were selected as study population. The patients were undergone CT-scan examination and the confirmation was performed by histopathological examination. The details of the pattern of tumor among the hepatocellular carcinoma patients were examined and were recorded. Result: A total number of 50 patients were recruited in this study after fulfilling the inclusion and exclusion criteria. Mean age with SD of study population was $48.78 \pm 12.07$. Within 25 cases of HCC as diagnosed by CT scan $13(52 \%)$ had solitary lesion $7(28 \%)$ had multiple lesions and remaining $5(20 \%)$ had diffuse lesions. The tumour size of $8 \mathrm{~cm}$ or more was the highest which was 10 in numbers. However, 4 to $8 \mathrm{~cm}$ was found in $7(28.0 \%)$ cases and 3 to $4 \mathrm{~cm}$ was detected in $3(12.0 \%)$ cases. Conclusion: In conclusion most of the HCC is solitary lesion with more than $8 \mathrm{~cm}$ in size. [Journal of Current and Advance Medical Research 2019;6(1):6-9]

Keywords: Pattern; Tumour; Hepatocelluar Carcinoma

Correspondence: Dr. Md. Akter Hossain, Associate Professor, Department of Radiology and Imaging, National Institute of Ophthalmology and Hospital, Dhaka; Email: akterdr@gmail.com; Cell no.: +8801819290848

Cite this article as: Hossain MA, Haque MS, Rahman MA, Nasreen Z, Bhuiya MA, Siddique AB. Pattern of Tumour among Hepatocelluar Carcinoma Patients attended at a Tertiary Care Hospital in Dhaka City. J Curr Adv Med Res 2019;6(1):6-9

Funding: This study has been performed without any funding from outside else.

Conflict of Interest: There was no conflict of interest to any of the authors.

Contributions to authors: Hossain MA, Haque MS, have contributed in protocol preparation, data collection, data analysis upto the report writing; Rahman MA, Nasreen Z, Bhuiya MA, Siddique AB have prepared \& have revised the manuscript.

Copyright: (92019. Hossain et al. Published by Journal of Current and Advance Medical Research. This article is published under the Creative Commons CC BY-NC License (https://creativecommons.org/licenses/by-nc/4.0/). This license permits use, distribution and reproduction in any medium, provided the original work is properly cited, and is not used for commercial purposes.

\section{Introduction}

Hepatocellular carcinoma (HCC) is the most common primary malignant liver tumor worldwide $^{1}$. Eighty-five percent of all cases occur in the context of chronic liver disease and cirrhosis 
of any etiology, but especially that associated with infection by Hepatitis B and $\mathrm{C}^{2}$. Only $15 \%$ occur in non-cirrhotic livers; however, patients with HCC have poor prognoses; it is the second leading cause of cancer-related death in men and the sixth in women ${ }^{3}$.

HCC develops in a manner similar to other solid tumors ${ }^{4}$. Especially in cirrhotic livers, hyperplastic nodules progress to low grade dysplastic nodules, then to early high grade $\mathrm{HCC}$ and then to $\mathrm{HCC}$ with even greater differentiation ${ }^{5}$. These changes depend on complex interactions among the host, the underlying disease and environmental factors ${ }^{6}$. Oxidative stress also plays an important role in carcinogenesis and tumor recurrence. In this context this present study was undertaken to see the pattern of hepatocellular carcinoma among the patients attended at a tertiary care hospital in Dhaka city.

\section{Methodology}

This descriptive cross-sectional study was carried out in the Department of Radiology and Imaging in Dhaka Medical College, Dhaka, Bagladesh and Banghabandhu Sheikh Mujib Medical University, Dhaka, Bangladesh from January 2007 to May 2008 for a period of around one and half year. All the patients presented with hepatocellular carcinoma at the age group of more than 20 years with both sexes were selected as study population. The patients were undergone CT-scan examination and the confirmation was performed by histopathological examination. During the study period, total 50 cases who had undergone CT-scan examination of Hepatobiliary system were included in this study done in DMCH and BSMMU, Dhaka with close cooperation of Gastroenterology and hepatobiliary departments. Prior to commencement of the study the local approval body approved the research protocol. Statistical analyses of the results were obtained by using window based computer software devised with Statistical Packages for Social Sciences (SPSS version 16.0).

\section{Result}

During study period of $17^{\text {th }}$ months, a total of 54 patients were selected on basis of clinical features and laboratory findings. Two were sensitive to contrast material; one had bleeding disorder and one lost histopathology report. So the study was carried out on 50 patients. A total number of 50 patients were recruited in this study after fulfilling the inclusion and exclusion criteria. Most of the hepatocellular carcinoma (44\%) was in the 41 to 50 years age group followed by 51 to 60 years which was $9(18.0 \%)$ cases. The youngest patient in this study was 22 years and the eldest 75 years. Mean age with SD of study population was $48.78 \pm 12.07$ (Table 1).

Table 1: Age Group Distribution of HCC Patients $(\mathbf{n}=50)$

\begin{tabular}{|l|c|c|}
\hline Age group & Frequency & Percent \\
\hline Less Than 30 Years & 3 & 6.0 \\
\hline 30 to 60 Years & 38 & 76.0 \\
More than 60 Years & 9 & 18.0 \\
Total & $\mathbf{5 0}$ & $\mathbf{1 0 0 . 0}$ \\
\hline
\end{tabular}

Within 25 cases of HCC as diagnosed by CT scan $13(52 \%)$ cases had solitary lesion; 7(28\%) cases had multiple lesions and remaining 5(20\%) had diffuse lesions (Table 2).

Table 2: Pattern of Tumors of the HCC Patients (n=50)

\begin{tabular}{|l|c|c|}
\hline Lesion & Frequency & Percent \\
\hline Solitary & 13 & 52.0 \\
\hline Multinodular & 7 & 28.0 \\
\hline Diffuse & 5 & 20.0 \\
\hline Total & $\mathbf{2 5}$ & $\mathbf{1 0 0 . 0}$ \\
\hline
\end{tabular}

It had been found that the tumour size of $8 \mathrm{~cm}$ or more was the highest which was 10 in numbers. However, 4 to $8 \mathrm{~cm}$ was found in $7(28.0 \%)$ cases and 3 to $4 \mathrm{~cm}$ was detected in $3(12.0 \%)$ cases (Table 3).

Table 3: Distribution of size of tumors $(n=25)$

\begin{tabular}{|l|c|c|}
\hline Size & Frequency & Percent \\
\hline 0 to $1 \mathrm{~cm}$ & 0 & 0.0 \\
\hline 1 to $2 \mathrm{~cm}$ & 1 & 4.0 \\
\hline 2 to $3 \mathrm{~cm}$ & 2 & 8.0 \\
\hline 3 to $4 \mathrm{~cm}$ & 3 & 12.0 \\
\hline 4 to $8 \mathrm{~cm}$ & 7 & 28.0 \\
\hline 8 cm or More & 10 & 40.0 \\
\hline Unknown & 2 & 8.0 \\
\hline Total & $\mathbf{2 5}$ & $\mathbf{1 0 0 . 0}$ \\
\hline
\end{tabular}

Group I was indicated the presence of extent of tumor better seen after I.V contrast; group II was shown the no difference; group III was represent the presence or extent of tumor better seen before IV contrast.

Table 4: Effect of intravenous (IV) contrast material on $\mathrm{HCC}(\mathrm{n}=25)$

\begin{tabular}{|l|c|c|}
\hline Group & Frequency & Percent \\
\hline Group - I & 5 & 20.0 \\
\hline Group - II & 9 & 36.0 \\
\hline Group - III & 11 & 44.0 \\
\hline
\end{tabular}

In $5(20 \%)$ cases presence on extent of tumor were better seen after IV contrast. In $9(36 \%)$ cases no 
difference were seen before and after IV contrast. In $11(44 \%)$ cases extent of tumor were better visualized before I.V contrast (Table 4).

\section{Discussion}

The differential diagnosis of HCC varies greatly depending on the underlying liver disease. In hepatitic/ cirrhotic livers, HCC, its precursor lesions and cholangiocellular carcinoma occur more frequently than malignant lesions of non-hepatic origin. In patients without underlying liver disease, HCC accounts only for about $2.0 \%$ of malignant liver neoplasms ${ }^{3}$. The most common primary sites that metastasize into the liver are lung, colon, pancreas and breast. In some cases metastasis can mimic hepatocellular carcinoma. The primary tumors resembling HCC include clear-cell renal cell carcinoma, clear-cell adenocarcinoma of the female genital organs, adrenal carcinoma and hepatoid adenocarcinoma of the stomach $^{7}$. Sometimes metastatic neuroendocrine tumors of the gastrointestinal tract, especially with trabecular growth pattern can also be difficult to distinguish from HCC.

During the study period from January 2007 to May 2008 total 50 cases were studied who had undergone CT examinations of Hepatobiliary system. The final diagnosis of HCC was made by histopathological examination in 38 cases.

In this study common age group affected by HCC was seen between 41 to 50 years and male female ratio seen was 6.6:1. In Britain, Hepatocellular carcinoma (HCC) was found over 50 years of age ${ }^{7}$. In Japan age distribution of HCC was found from 5 years to 100 years with a mean age of 55.5 years $^{3}$. In Bangladesh, HCC was found to be common between 41 to 50 years of age group ${ }^{8}$. In this study, age of the youngest patient with HCC was 22 years and that of the eldest one was 75 years. The diseases was found to be common between 41 to 50 years of age group which correlated with the above study done in Bangladesh.

In my study it was seen that by evaluating $\mathrm{CT}$, out of 25 patients of HCC $13(52 \%)$ patients had solitary lesions, other $7(28 \%)$ patients had multiple lesions and further $5(20 \%)$ patients had diffuse lesion. In a similar study done by Kunstlinger et $\mathrm{al}^{9}$ found $53.0 \%$ patients of HCC had solitrary lesion, $27.0 \%$ had multifocal lesion and rest $20.0 \%$ had diffuse lesions. So, this present study closely correlates with the above study.

In this study size of the main tumor were evaluated. Size of the main tumor was up to $8 \mathrm{~cm}$ in $13(52.0 \%)$ cases of more than $8 \mathrm{~cm}$ was in
10(40.0\%) patients. In 2(8.0\%) cases tumor size could not be detected. Tumor size less than $3 \mathrm{~cm}$ was found in 3 cases. Similar study done by Itai et $\mathrm{al}^{10}$ found that tumor size was up to $8 \mathrm{~cm}$ in $55 \%$ cases and more than $8 \mathrm{~cm}$ in $38 \%$ of cases. In $6 \%$ cases tumor size was unknown. Smaller tumour $(<3$ $\mathrm{cm})$ were detected in similar manner like our study. So this study is also correlated with the above study regarding tumor size.

In this study effect of IV contrast material on HCC was evaluated. The effects of contrast material after I.V. injection were grouped as, Group-I; presence or extent of tumor better seen after I.V contrast, Group-II: No difference and Group-III: presence or extent of tumor better seen before I.V. contrast. In this study $9(23 \%) 13(34 \%)$ and $16(42 \%)$ cases were included within group I, II and III respectively. Kunstlinger et $\mathrm{al}^{9}$ found the effect of I.V contrast material on HCC by similar manner. In that study $15.0 \%, 38.0 \%$ and $46.0 \%$ cases were seen to be included in group I, II and III respectively which closely correlates with our present study.

CT-scan before and after intravenous administration of contrast agent is an excellent method for evaluating hepatic lesions. Cystic lesions are readily identified and abscesses are usually distinguished from tumors. Masses as small as $1 \mathrm{~cm}$ can usually be identified by CT-scan and the lesions can be biopsied under CT guidance.

Intravenously administered iodinated contrast material increases the density of the liver. Scans made soon after infusion or injection show the greatest opacification ${ }^{11}$. Contrast enhancement of any organ and lesion depends on the size of their vascular and interstitial compartments ${ }^{12}$.

If the goal of CT examination is detection of hypervascular hepatic lesions, use of contrast enhanced CT alone may be adequate and addition of unenhanced scans is not cost effective $\mathrm{e}^{13-15}$.

\section{Conclusion}

In conclusion most of the HCC is solitary lesion followed by multiple lesions and diffuse lesions. Furthermore the size of the majority tumor is more than $8 \mathrm{~cm}$ in size followed by 4 to $8 \mathrm{~cm}$. Regarding use of contrast to visualize HCC tumor, most of the tumor is better visualized before contrast. This is a small scale study in a single centred based. Therefore a large scale study should be carried out to see the real scenario about the HCC.

\section{References}

1. Venook AP, Papandreou C, Furuse J, de Guevara LL. The 
incidence and epidemiology of hepatocellular carcinoma: a global and regional perspective. The oncologist. 2010;15(Supplement 4):5-13

2. Ferlay J, Shin HR, Bray F, Forman D, Mathers C, Parkin DM. Estimates of worldwide burden of cancer in 2008: GLOBOCAN 2008. Int J Cancer 2010; 127: 2893-2917

3. Bosch FX, Ribes J, Díaz M, Cléries R. Primary liver cancer: worldwide incidence and trends. Gastroenter 2004;127: S5-S16 4. Sherman M. Hepatocellular carcinoma: epidemiology, risk factors, and screening. Seminars in Liver Disease 2005;25(02):143-154

5. El-Serag HB. Epidemiology of viral hepatitis and hepatocellular carcinoma. Gastroenter. 2012; 142(6): 1264-73

6. El-Serag HB. Hepatocellular carcinoma: an epidemiologic view. J Clin Gastroenter 2002; 35(5): S72-8

7. Krasner N. HCC in Britain, Gut 1978;19(11):1022

8. Alam MR. Needle biopsy of liver, a study of 100 cases (Dissertation), IPGMR, Dhaka, 1989

9. Kunstlinger F, Federle MP, Moss AA, Marks W. Computed tomography of hepatocellular carcinoma. American Journal of Roentgenology. 1980;134(3):431-7
10. Itai $\mathrm{Y}$, Ohtomo K, Kokubo T, Yamauchi T, Minami M, Yashiro N, et al. CT-scan of hepatic masses: significance of prolonged and delayed enhancement. Am J Roentgen 1986;146(4):729-33

11. Schlageter M, Terracciano LM, D'Angelo S, Sorrentino P. Histopathology of hepatocellular carcinoma. World Journal of Gastroenterology: WJG. 2014;20(43):15955.

12. Anzola M. Hepatocellular carcinoma: role of hepatitis B and hepatitis $\mathrm{C}$ viruses proteins in hepato-carcinogenesis. $\mathbf{J}$ Viral Hepat. 2004;11:383-393

13. Bralet MP, Régimbeau JM, Pineau P, Dubois S, Loas G, Degos F, et al. Hepatocellular carcinoma occurring in nonfibrotic liver: epidemiologic and histopathologic analysis of 80 French cases. Hepatology. 2000;32:200-204

14. Tobe T, Kameda H, Okudaira M, Ohto M, Endo Y, Mito $\mathrm{M}$, et al. editors. Primary liver cancer in Japan. Springer Science \& Business Media; 2012 Dec 6.

15. Wallace MC, Preen D, Jeffrey GP, Adams LA. The Evolving epidemiology of hepatocellular carcinoma: a global perspective. Expert Rev Gastroenterol Hepatol. 2015;1:1-15 